\title{
Orthognathic surgery: doubts from patients with orofacial fissures regarding the immediate postoperative period
}

\author{
Cirurgia ortognática: dúvidas de pacientes com fissuras orofaciais referentes ao pós-operatório imediato \\ Cirugía ortognática: dudas de pacientes con fisuras orofaciales referentes al postoperatorio inmediato
}

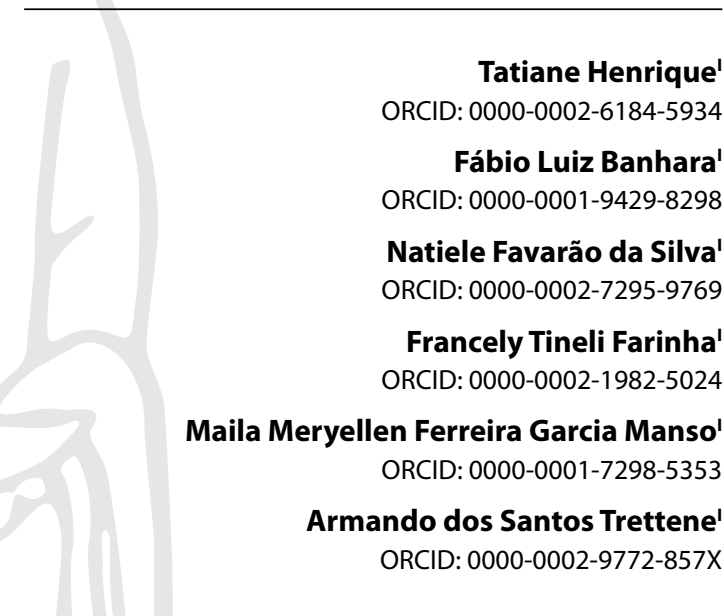

'Universidade de São Paulo, Hospital de Reabilitação de Anomalias Craniofaciais. Bauru, São Paulo, Brazil.

How to cite this article: Henrique T, Banhara FL, Silva NF, Farinha FT, Manso MMFG, Trettene AS. Orthognathic surgery:

doubts from patients with orofacial fissures regarding the immediate postoperative period.

Rev Bras Enferm. 2021;74(2):e20200089. https://doi.org/10.1590/0034-7167-2020-0089

Corresponding author: Armando dos Santos Trettene E-mail: armandotrettene@usp.br

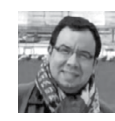

EDITOR IN CHIEF: Dulce Barbosa ASSOCIATE EDITOR: Marcia Magro

Submission: 04-18-2020

Approval: $12-21-2020$

\begin{abstract}
Objectives: to identify the main doubts regarding the immediate postoperative care of patients with orofacial clefts undergoing orthognathic surgery. Methods: cross-sectional, quantitative study, developed in a public and tertiary hospital, between November 2017 and May 2018. Data collection occurred through interviews during the preoperative nursing consultation. An instrument was used to describe doubts, which later were grouped according to the subject. Results: 48 patients participated. The doubts referred to sun exposure (56\%), food/mastication ( $48 \%$ ), the relationship between intermaxillary block-breathing-vomiting $(48 \%)$, oral hygiene (31\%), physical activity restriction (27\%), nasopharyngeal cannula, removal of surgical stitches, hospitalization time and speech/communication (23\%), bleeding, cryotherapy, facial massage, aesthetic and functional results, healing, edema/ecchymosis, postoperative pain, and changes in facial sensitivity (21\%). Conclusions: the doubts were related to food, the period of convalescence, care for the surgical wound, postoperative complications, and medications.
\end{abstract}

Descriptors: Orthognathic Surgery; Nursing; Postoperative Period; Cleft Lip; Cleft Palate.

\section{RESUMO}

Objetivos: identificar as principais dúvidas, referentes aos cuidados do pós-operatório imediato, de pacientes com fissuras orofaciais submetidos à cirurgia ortognática. Métodos: estudo transversal, quantitativo, desenvolvido em um hospital público e terciário, entre novembro de 2017 e maio de 2018. A coleta de dados ocorreu por meio de entrevista durante a consulta de enfermagem préoperatória. Utilizou-se um instrumento para descrever as dúvidas, que, posteriormente, foram agrupadas conforme o assunto. Resultados: participaram 48 pacientes. As dúvidas referiram-se à exposição ao sol (56\%), alimentação/mastigação (48\%), relação entre bloqueio intermaxilar-respiração-vômito $(48 \%)$, higiene oral $(31 \%)$, restrição da atividade física (27\%), cânula nasofaríngea, retirada dos pontos cirúrgicos, tempo de internação e fala/comunicação (23\%), sangramento, crioterapia, massagem facial, resultados estéticos e funcionais, cicatrização, edema/equimose, dor pós-operatória e alterações na sensibilidade facial (21\%). Conclusões: as dúvidas se relacionaram à alimentação, período de convalescência, cuidados com a ferida operatória, complicações pós-operatórias e medicações. Descritores: Cirurgia Ortognática; Enfermagem; Período Pós-operatório; Fenda Labial; Fissura Palatina.

\section{RESUMEN}

Objetivos: identificar las principales dudas, sobre los cuidados del postoperatorio inmediato, de pacientes con fisuras orofaciales sometidos a la cirugía ortognática. Métodos: estudio transversal, cuantitativo, desarrollado en hospital público y terciario, entre noviembre de 2017 y mayo de 2018. La recogida de datos ocurrió por medio de entrevista durante la consulta de enfermería preoperatoria. Utilizó un instrumento para describir las dudas, que, posteriormente, fueron agrupadas conforme el asunto. Resultados: participaron 48 pacientes. Las dudas se refirieron a la exposición al sol (56\%), alimentación/masticación (48\%), relación entre bloqueo intermaxilar-respiración-vómito (48\%), higiene oral (31\%), restricción de la actividad física (27\%), cánula nasofaríngea, retirada de los puntos quirúrgicos, tiempo de internación y habla/comunicación (23\%), hemorragia, crioterapia, masaje facial, resultados estéticos y funcionales, cicatrización, edema/equimosis, dolor postoperatorio y alteraciones en la sensibilidad facial (21\%). Conclusiones: las dudas se relacionaron a la alimentación, período de convalecencia, cuidados con la herida operatoria, complicaciones postoperatorias y medicaciones.

Descriptores: Cirugía Ortognática; Enfermería; Período Postoperatorio; Fisura Labial; Fisura Palatina. 


\section{INTRODUCTION}

Orofacial clefts, better known as lip and/or palate, are prevalent among malformations affecting the face, whose incidence in Brazil is 1 in every 700 live births. Of multifactorial etiology, which includes genetic and environmental factors, they develop in the embryonic period and early fetal period, that is, between the 4th and 12th week of pregnancy. They can affect the lip, alveolar ridge, and palate alone or in association. Thus, the greater the anatomical impairment, the greater will be the functional, aesthetic, and psychosocial implications $\mathbf{s}^{(1-2)}$.

The rehabilitative process takes time: it begins in childhood and extends into adulthood, requiring multidisciplinary and interdisciplinary treatment. Although the benefits of primary surgeries performed in childhood are evident, they may result in a rigid and fibrosis labial belt in the region of the maxilla and cause damage to the bone growth of the face, including maxillary development, leading to dentofacial deformities such as dental malocclusion. The most common type of malocclusion found in patients with a cleft is the Angle Class III, requiring orthognathic surgery for its correction ${ }^{(3)}$.

In other words, orthognathic surgery aims to repair maxillomandibular and facial impairments. For patients with cleft lip and/or palate, it should be performed at the end of facial development, provided that the patient has undergone previous alveolar bone grafting surgery ${ }^{(4)}$.

The surgical procedure benefits include aesthetic and functional improvements, such as better breathing, mastication, hearing, and speech $^{(5-8)}$. Besides, there are benefits related to improvements in the perception of the quality of life $\mathrm{e}^{(9)}$.

Complications of orthognathic surgery include: nerve damage, surgical site infection, temporomandibular dysfunction, undue fracture, scar alteration, bleeding, exacerbated pain, soft tissue laceration, dental injury, and problems with fixation material|(10-11).

In this context, in the postoperative period, nursing interventions should focus on preventing surgical complications, monitoring sensitivity, motor skills, pain management, and anxiety control ${ }^{(3,12)}$.

Postoperative care includes diet changes, oral hygiene, alterations in physiognomy to overcome the onset of edema and bruising, the need to use intermaxillary blockade, pain monitoring, and difficulties related to verbal communication. In this situation, the nursing staff should teach or train patients and their caregivers to maintain care at home, whose quality will influence the therapeutic success. Thus, guidelines should start in the preoperative period and extend until the hospital discharge $\mathrm{e}^{(12-13)}$.

The nurse plays a fundamental role in training and clarification of doubts since resolving them reduces the insecurity of the patient and his family ${ }^{(12-14)}$.

Therefore, the question is: What are the main doubts concerning the immediate postoperative orthognathic surgery period in patients with cleft lip and/or palate?

Considering the increase in oral and maxillofacial surgeries, among them orthognathic, the decentralization of health services, as well as the scarcity of studies on this subject, especially those developed by nurses, this investigation is expected to provide elements to plan for the care of quality nursing, humanized and safe, focused on the real needs of the clientele.

\section{OBJECTIVES}

To identify the main doubts, concerning the immediate postoperative of orthognathic surgery, from patients with orofacial fissures.

\section{METHODS}

\section{Ethical Aspects}

The research started after the Research Ethics Committee's approval involving human beings of the institution. The participants formalized their adhesion to this research by signing the Term of Free and Informed Consent, in compliance with Resolution 466/2012.

\section{Design, period, and place of study}

This study is a descriptive, cross-sectional, quantitative design study guided by STROBE, conducted in a public, tertiary hospital, with reference in care for patients with craniofacial anomalies and related syndromes in the countryside of the state of São Paulo, Brazil. The hospital has 91 beds; the service is interdisciplinary and humanized, and the unit contemplated in this study was the hospitalization unit.

\section{Population, criteria of inclusion, and definition of sample}

The population consisted of patients in the preoperative period of orthognathic surgery. They included patients aged 18 years or older who underwent exclusively orthognathic surgery. The study excluded patients with communication deficits that made data collection impossible.

The sample consisted of 48 participants, considering the monthly average of surgeries (eight) and the stipulated time for data collection (six months).

\section{Study Protocol}

Data collection occurred during the preoperative nursing consultation, specifically by the researchers. Aspects related to the patient's preparation for the surgical procedure were addressed, including checking the fasting start time, as well as its maintenance, the general condition of the patient, complications presented in the last 24 hours, previous pathologies, use of medication, need for medical evaluation, expectations about the surgical procedure and significant doubts related to the postoperative period.

For data collection, researchers used a structured interview. Initially, participants received information about the surgical procedure, which included indication, mean time of surgery, and aspects related to anesthesia. Subsequently, researchers asked them about their doubts and wrote it in a form prepared for that purpose.

The interviews took place in a private room, individually, and lasted an average of 20 minutes. The study characterized participants according to variables, such as gender, age, education, socioeconomic classification $^{(15)}$, marital status, and the number of children.

The researchers conducted the data collection between November 2017 and May 2018. 


\section{Analysis of results and statistics}

We chose to group the doubts by subject to facilitate the presentation of the results. This grouping was established by similarity. After identifying the doubts, they were grouped according to the subject they addressed: for example, those related to food included the type of food, consistency, temperature, among others.

The results were tabulated in an Excel spreadsheet (2015 version) and submitted to descriptive statistical analysis, including the mean, standard deviation, relative and absolute frequencies.

\section{RESULTS}

48 patients participated in this study; average age was 24 years $(S D=5.5)$. Prevalence was female gender $(n=27 ; 56 \%)$, complete high school ( $n=19 ; 40 \%)$, upper low class $(n=33 ; 69 \%)$, without children $(n=46 ; 96 \%)$, single $(n=29 ; 60 \%)$ (Table 1$)$.

Table 1 - Distribution of participants according to variables: gender, education, social class, number of children and marital status, Bauru, São Paulo, Brazil, 2018

\begin{tabular}{|c|c|c|}
\hline Variables & $\mathbf{n}$ & $\%$ \\
\hline \multicolumn{3}{|l|}{ Gender } \\
\hline Female & 27 & 56 \\
\hline Male & 21 & 44 \\
\hline \multicolumn{3}{|l|}{ Education } \\
\hline Complete High School & 19 & 40 \\
\hline Incomplete undergraduate & 15 & 31 \\
\hline Complete undergraduate & 10 & 21 \\
\hline Incomplete High School & 2 & 4 \\
\hline Incomplete Elementary School & 2 & 4 \\
\hline \multicolumn{3}{|l|}{ Social Class } \\
\hline Upper Low class & 33 & 69 \\
\hline Low Middle Class & 11 & 23 \\
\hline Middle Class & 4 & 8 \\
\hline \multicolumn{3}{|l|}{ Children } \\
\hline No & 46 & 96 \\
\hline Yes & 2 & 4 \\
\hline \multicolumn{3}{|l|}{ Marital Status } \\
\hline Single & 29 & 60 \\
\hline Dating & 11 & 23 \\
\hline Married & 6 & 13 \\
\hline Stable Union & 2 & 4 \\
\hline
\end{tabular}

Table 2 - Distribution of participants about doubts related to the immediate postoperative period of orthognathic surgery, Bauru, São Paulo, Brazil, 2018

\begin{tabular}{lcc}
\hline Variables & $\mathbf{n}$ & $\%$ \\
\hline Sun exposure & 27 & 56 \\
$\begin{array}{l}\text { Food (type of food, consistency, temperature, and time } \\
\text { period) and mastication }\end{array}$ & 23 & 48 \\
Relationship between intermaxillary blockage and breathing & 23 & 48 \\
process & 15 & 31 \\
Oral hygiene & 13 & 27 \\
Relationship between intermaxillary blockage and vomit & 13 & 27 \\
Physical activity restriction & 11 & 23 \\
Use of nasopharyngeal cannula & 11 & 23 \\
Stitch removal & 11 & 23 \\
Hospitalization time & 11 & 23 \\
Speech/Communication & 10 & 21 \\
Bleeding & &
\end{tabular}

To be continued

\begin{tabular}{lcc} 
Table 2 (concluded) & n & $\%$ \\
\hline Variables & 10 & 21 \\
\hline Cryotherapy & 10 & 21 \\
Facial massage & 10 & 21 \\
Expected aesthetic and functional results & 10 & 21 \\
Cicatrization & 10 & 21 \\
Edema/Ecchymosis & 10 & 21 \\
Post-operative pain & 10 & 21 \\
Changes in facial sensitivity & 10 & 21 \\
Medications (antibiotic therapy, analgesics, and anti- & &
\end{tabular}

Table 3 - Topics after grouping patients' doubts about the immediate postoperative period of orthognathic surgery, Bauru, São Paulo, Brazil, 2018

\begin{tabular}{lcc}
\hline Themes arising from the grouping of doubts & $\mathbf{n}$ & $\%$ \\
\hline $\begin{array}{l}\text { Convalescence period (sun exposure, physical effort, time } \\
\text { away from activities, length of hospitalization, aesthetic, } \\
\text { and functional results) }\end{array}$ & 27 & 56 \\
$\begin{array}{l}\text { Food (type of food, consistency, temperature, and time } \\
\text { period) }\end{array}$ & 23 & 48 \\
$\begin{array}{l}\text { Postoperative complications (relationship between } \\
\text { intermaxillary blockade and the breathing process, } \\
\text { relationship between intermaxillary blockade and } \\
\text { vomiting, use of nasopharyngeal cannula, bleeding, } \\
\text { cryotherapy, facial massage, Edema/ Ecchymosis, } \\
\text { postoperative pain, changes in facial sensitivity) } \\
\begin{array}{l}\text { Care of the operative wound (oral hygiene, removal of } \\
\text { surgical stitches, healing) }\end{array}\end{array}$ & 23 & 48 \\
$\begin{array}{l}\text { Medications (antibiotic therapy, analgesics, and anti- } \\
\text { inflammatories) }\end{array}$ & 15 & 31 \\
\hline
\end{tabular}

About patients' doubts on the immediate postoperative period of orthognathic surgery prevailed sun exposure ( $n=27 ; 56 \%$ ), food/mastication ( $n=23 ; 48 \%)$ and relationship between intermaxillary blockade and breathing process ( $n=23 ; 48 \%$ ) (Table 2$)$. It is noteworthy that each participant had more than one answer.

After identifying the doubts, researchers formed groups according to the similarity of subjects, including food, care for the surgical wound, post-operative complications, period of convalescence, and medications. There was a predominance of the theme"period of convalescence," which included the variables sun exposure, physical effort, time away from activities, time of hospitalization, aesthetic, and functional results $(56 \% ; n=27)$ (Table 3 ).

\section{DISCUSSION}

In this study, the average age of the participants was 24 years, hence young. Most were single, without children, and had completed high school. Orthognathic surgery should be performed at the end of bone growth, which usually occurs in late adolescence. However, in patients with cleft lip and/or palate, it is necessary to perform the alveolar bone grafting and previous orthodontic treatment ${ }^{(16)}$.

As for the gender, the prevalence of women was evident, although there has been a predominance of this surgical procedure with cleft lip in male patients ${ }^{(1,17)}$.

About the socioeconomic classification, the low class was predominant. It is noteworthy that orthognathic surgery is a high-cost procedure. Thus, populations in need seek public 
institutions that offer the procedure for free, such as the hospital in which this research was conducted, which is managed entirely with public resources ${ }^{(15,18)}$.

The grouping of doubts by similarity resulted in themes: food, care for the surgical wound, postoperative complications, period of convalescence, and medications. A similar result was observed in another investigation whose objective was to know patients' and caregivers' doubts about another orofacial surgery ${ }^{(18)}$.

According to the institution's protocol where the study was conducted, it is recommended that, after hospital discharge, the patient avoids intense physical exercise and stay away from work for 60 days to prevent possible complications. It is also recommended to avoid sun exposure for at least 30 days and to use sunscreen.

In general, the patients remain hospitalized for 48 hours, although it is possible to discharge them within 12 hours ${ }^{(19)}$. Therefore, it must be taken into consideration the patient's clinical stability, food acceptance, and ability to change the elastic bands ${ }^{(20)}$.

Another aspect associated with limited mouth opening refers to communication problems, especially considering the verbalization of words. Thus, some strategies must be incorporated, such as written communication. The presence of a companion also favors communication ${ }^{(13,18)}$.

Another doubt referred to the aesthetic and functional benefits of the surgery, which, although desired immediately, are evidenced in the medium and long term ${ }^{(4)}$. They include improved respiratory capacity, mastication, speech quality, and facial harmony, in addition to psycho-emotional aspects, such as self-esteem and better perception of the quality of life ${ }^{(5,8-9)}$.

As for the topic "food," the doubts were related to the type of food, consistency, temperature, and period of time. In fact, with orthognathic surgery, it is necessary to modify the consistency of the diet, i.e., it is recommended that the patient eat foods of liquid and cold consistency for 30 days because the opening of mouth and mastication are impaired ${ }^{(19,21)}$.

Food should be cooked and beaten in a blender. It can be mixed with juices, milk, water, or broths, remembering the importance of providing balanced meals since the patient's nutritional status is related to the healing process and contributes to reverse the catabolic metabolism resulting from the surgery, favoring recovery. After this period, the patient will be able to ingest pasty foods, such as purees. For those whose food acceptance is insufficient, it is indicated the use of supplements ${ }^{(21-22)}$.

It is a known fact that trauma and/or surgical stress generate a hypermetabolic state, causing an increased need for energy and protein. So, it becomes essential to monitor food acceptance because poor nutrition predisposes to postoperative complications ${ }^{(22)}$.

About "postoperative complications," doubts included the association between intermaxillary blockade with elastic bands and breathing and vomiting, the use of a nasopharyngeal cannula, bleeding, cryotherapy, facial massage, edema/ecchymosis, postoperative pain, and changes in facial sensitivity.

Intermaxillary blockade with elastic bands is commonly used in the postoperative period, whose function is to exert traction force on the teeth helping in the correct dental positioning, and the elastic bands should be positioned on the hooks of the fixed appliance and changed daily and properly. The use of these elastic bands brings concerns to patients since they limit the mouth opening, with repercussions on masticating, feeding, breathing, and the risk of asphyxia, in cases of vomiting, for example ${ }^{(19)}$.

In fact, in the postoperative period, nausea and vomiting are among the most frequent and also undesirable symptoms because of the risk of asphyxia. In patients undergoing orthognathic, vomiting is usually related to the blood swallowed during the surgical procedure and anesthetic procedure. Thus, sometimes it is necessary to maintain fasting in the first hours of postoperative ${ }^{(23)}$. It is necessary to guide patients and their families about the elastic bands' insertion and their removal to minimize these effects. Other measures can be implemented, such as raising the headboard and the administration of antiemetics.

The institution where this study was conducted uses the nasopharyngeal cannula routinely to aim at airway permeability, introducing it into both nostrils shortly after extubation and maintaining it for the first 24 hours.

Bleeding after orthognathic surgery is rare, and compression with gauze or cold compresses is effective for treatment in lowintensity bleedings ${ }^{(24)}$. However, signs and symptoms of bleeding should be systematically monitored, especially in the immediate postoperative period ${ }^{(23)}$.

As far as cryotherapy is concerned, it is recommended in the postoperative period for the treatment of pain, edema, and inflammation because it promotes slowness of painful impulses that are conducted to the brain, minimizing muscle spasm, decreasing the activity of inflammatory enzymes, and promoting vasoconstriction, in addition to preventing bleeding and bruising. Massage, cryotherapy, and facial lymphatic drainage contribute to reducing edema, which is accentuated in the first days after surgery ${ }^{(19,25)}$.

The pain is related to the surgical act itself and several factors, such as contraction of peripheral soft tissues and surrounding muscle stiffness ${ }^{(26)}$. Its control improves respiratory function, promotes hemodynamic stability, inhibits hormonal and metabolic reactions, and decreases hospitalization time ${ }^{(27)}$. Assessing facial sensitivity in the postoperative period, especially in the chin, lower lip, and cheek should also be emphasized, as there may be an injury in the lower alveolar nerve during the surgical procedure ${ }^{(28)}$.

It is noteworthy that intubation and surgical technique cause oral wounds with consequent edema of the associated structures, causing pain and/or discomfort and may compromise the frequency and quality of oral hygiene. Therefore, the dentist should provide oversight to whom teaches and supervises oral hygiene. It is also indicated that water-based mouthwash ${ }^{(19)}$, such as $0.12 \%$ chlorhexidine, is associated with brushing four to six times a day ${ }^{(29)}$. Oral hygiene is the main factor in the prevention of surgical site infection in orofacial surgeries and should be performed with a brush and toothpaste, as usual, minimally after meals ${ }^{(18)}$.

There is no need to remove the stitches used to suture the incision because they are absorbable ${ }^{(29)}$. Healing is a complex process and is influenced by several factors, varying from individual to individual. Knowing this, it is important that after the surgical intervention, the patient performs all the recommended instructions, including vigilance of the healing process and monitoring postoperative complications ${ }^{(19,25)}$.

Another topic was about the medications used. Opioids are used to treat pain in the immediate postoperative period, while traditional analgesics are used in the mediate period ${ }^{(26)}$. However, 
the administration of non-steroidal anti-inflammatory drugs is also frequently employed, depending on the patient's pain threshold. In addition to those medications, there are also used dexamethasone, which has the purpose of reducing orofacial edema caused by surgical intervention, and droperidol, which presents satisfactory effect in the prevention of nausea and vomiting ${ }^{(30)}$.

Also, to minimize the infection of the surgical site, besides adopting an aseptic surgical technique, it is necessary to administer prophylactic antibiotics. Cefazolin has proved to be effective, being the drug of choice ${ }^{(31)}$. The implementation of surveillance and follow-up after hospital discharge is a way to minimize the incidence of surgical site infections and other complications ${ }^{(32)}$.

\section{Study Limitations}

The study in a single center and with a specific population limits the generalization of the results.

\section{Contributions to the field of Nursing}

This investigation's benefits are evident and include nursing care focused on the real needs of the patients, which should begin in the preoperative phase by providing guidance and strengthening the decision-making process. Correctly oriented patients feel better prepared for the surgical procedure, present better coping with the difficulties experienced in the postoperative period, besides acquiring knowledge about care.

\section{CONCLUSIONS}

The doubts were related to food, period of convalescence, care for the surgical wound, postoperative complications, and medications. Based on them, it was possible to plan and implement a nursing assistance aimed at the real needs of patients, promoting self-care, and favoring postoperative rehabilitation.

\section{REFERENCES}

1. Freitas JAS, Neves LT, Almeida ALPF, Garib DG, Trindade-Suedam IK, Yaedú RYF, et al. Rehabilitative treatment of cleft lip and palate: experience of the Hospital for Rehabilitation of Craniofacial Anomalies/USP (HRAC/USP) - Part 1: overall aspects. J Appl Oral Sci [Internet]. 2012 [cited 2019 Jan 17];20(1):9-15. Available from: http://www.scielo.br/pdf/jaos/v20n1/03.pdf

2. François CF, Poli MLM, Nguyen P, Landais E, Gaillard D, Doco MF. Role of angiogenesis-related genes in cleft lip/palate: review of the literature. Int J Pediatr Otorhinolaryngol [Internet]. 2014 [cited 2019 Jan 17];78(10):1579-85. Available from: http://www.ijporlonline.com/ article/S0165-5876(14)00445-5/fulltext

3. Graziani AF, Garcia CFS, Felix GB, Genaro KF. Orthognathic surgery effect of orofacial sensitivity in individuals eith cleft lip and palate. Rev CEFAC [Internet]. 2016 [cited 2019 Jan 17];18(3):581-8. Available from: http://www.scielo.br/pdf/rcefac/v18n3/1982-0216rcefac-18-03-00581.pdf

4. Medeiros MNL, Ferlin F, Fukushiro AP, Yamashita RP. Speech resonance after surgical management of velopharyngeal insufficiency secondary to orthognathic surgery. Rev CEFAC [Internet]. 2015 [cited 2019 Jan 17];17(2):418-25. Available from: http://www.scielo.br/pdf/ rcefac/v17n2/1982-0216-rcefac-17-02-00418.pdf

5. Pedroso-Oliveira G, Cavalieri-Pereira L, Brancher GQB, Macedo CJO, Cerezetti L, Cavalieri-Pereira S. Maxilla pseudoarthrosis ten years after orthognathic surgery: case report. Int J Odontostomat [Internet]. 2019 [cited 2019 Apr 17];13(4):504-10. Available from: https://scielo. conicyt.cl/pdf/ijodontos/v13n4/0718-381X-ijodontos-13-04-00504.pdf

6. Rodrigues WC, Gabrielli MFR, Oliveira MR, Piveta ACG, Gabrielli MAC. Orthodontic-surgical treatment of a patient with Marfan Syndrome and Obstructive Sleep Apnea Syndrome: a case report with a 9-year follow-up. Rev Gaúch Odontol [Internet]. 2019 [cited 2019 Apr 17];67:e20190050. Available from: http://www.scielo.br/pdf/rgo/v67/1981-8637-rgo-67-e20190050.pdf

7. Naran S, Steinbacher DM, Taylor JA. Current Concepts in Orthognathic Surgery. Plast Reconstr Surg. 2018;141(6):925-36. https://doi. org/10.1097/PRS.0000000000004438

8. Coelho JS, Vieira RC, Bianchini EMG. Interference of dentofacial deformities in the acoustic characteristics of speech sounds. Rev CEFAC [Internet]. 2019 [cited 2019 Apr 17];21(4):e19118. Available from: http://www.scielo.br/pdf/rcefac/v21n4/1982-0216-rcefac-21-04-e19118.pdf

9. Torres KV, Pessoa LS, Luna AHB, Alves GAS. Quality of life after orthognathic surgery: a case report. Rev CEFAC [Internet]. 2017 [cited 2019 Apr 17];19(5):733-9. Available from: http://www.scielo.br/pdf/rcefac/v19n5/1982-0216-rcefac-19-05-00733.pdf

10. Haas Junior OL, Meirelles LS, Scolari N, Becker OE, Melo MFS, Oliveira RB. Bone grafting with granular biomaterial in segmental maxillary osteotomy: a case report. Int J Surg Case Rep [Internet]. 2016 [cited 2019 Apr 17];25:238-42. Available from: https://www.ncbi.nlm.nih.gov/ pmc/articles/PMC4942733/pdf/main.pdf

11. Haas Jr OL, Guijarro-Martínez R, Sousa Gil AP, Silva Meirelles L, Oliveira RB, Hernández-Alfaro F. Stability and surgical complications in segmental Le Fort I osteotomy: a systematic review. Int J Oral Maxillofac Surg. 2017;46(9):1071-87. https://doi.org/10.1016/j.ijom.2017.05.011

12. Assis GLC, Sousa CS, Turrini RNT, Poveda VB, Silva RCG. Proposal of nursing diagnoses, outcomes and interventions for postoperative patients of orthognathic surgery. Rev Esc Enferm USP [Internet]. 2018 [cited 2019 Jan 17];52:e03321. Available from: http://www.scielo.br/ pdf/reeusp/v52/0080-6234-reeusp-S1980220X2017025303321.pdf

13. Almeida RJ, Cunha GFM, Santos EAMC, Bom CG, Mendonça JSC, Trettene AS. Questions of informal caregivers of children regarding the postoperative period of cochlear implant. Rev Bras Enferm [Internet]. 2019 [cited 2019 Apr 17];72(4):988-93. Available from: http://www. scielo.br/pdf/reben/v72n4/0034-7167-reben-72-04-0988.pdf 
14. Sousa CS, Turrini RNT. Development of an educational mobile application for patients submitted to orthognathic surgery. Rev LatinoAm Enfermagem [Internet]. 2019 [cited 2019 Apr 17];27:e3143. Available from: http://www.scielo.br/pdf/rlae/v27/en_1518-8345-rlae27-e3143.pdf

15. Graciano MIG, Souza EG, Rosa JA, Blattner SHB. Validação de conteúdo de um instrumento de avaliação socioeconômica no âmbito do Serviço Social. RIPE: Const Serv Soc [Internet]. 2015 [cited 2019 Jan 17];19(36):29-57. Available from: http://ojs.ite.edu.br/index.php/css/ article/viewFile/214/253

16. Freitas JAS, Garib DG, Trindade-Suedam IK, Carvalho RM, Oliveira TM, Lauris RCMC, et al. Rehabilitative treatment of cleft lip and palate: experience of the Hospital for Rehabilitation of Craniofacial Anomalies - USP (HRAC-USP) - Part 3: Oral and Maxillofacial Surgery. J Appl Oral Sci. 2012;20(6):673-9. https://doi.org/10.1590/S1678-77572012000100003

17. Xiao Y, Taub MA, Ruczinski I, Begum F, Hetmanski JB, Schwender $\mathrm{H}$, et al. Evidence for SNP-SNP interaction identified through targeted sequencing of cleft case-parent trios. Genet Epidemiol Sci. 2017;41(3):244-50. https://doi.org/10.1002/gepi.22023

18. Silva NF, Beluci ML, Banhara FL, Henrique T, Manso MMFG, Trettene AS. Patients and informal caregivers' questions about alveolar bone graft post-operative care. Rev Bras Enferm. 2020;73(5):e20190403. Available from: https://doi.org/10.1590/0034-7167-2019-0403

19. Santos MRM, Sousa CS, Turrini RN. Perception of Orthognathic surgery patients on Postoperative care. Rev Esc Enferm USP [Internet]. 2012 [cited 2019 Jan 17];46(Esp):78-85. Available from: http://www.scielo.br/pdf/reeusp/v46nspe/12.pdf

20. Alves e Silva AC, Carvalho RAS, Santos TS, Rocha NS, Gomes ACA, Oliveira e Silva ED. Evaluation of life quality of patients submitted to orthognathic surgery. Dental Press J Orthod. 2013;18(5):107-14. https://doi.org/10.1590/S2176-94512013000500018

21. Giridhar VU. Role of nutrition in oral and maxillofacial surgery patients. Natl J Maxillofac Surg [Internet]. 2016 [cited 2019 Jan 17];7(1):3-9. Available from: https://www.ncbi.nlm.nih.gov/pmc/articles/PMC5242071/

22. Beluci ML, Barros SP, Borgo HC, Fontes CMB, Arena EP. Postsurgical alveolar bone graft patients: elaboration and application of a datagathering instrument for nutrition and nursing. Cleft Palate-Craniof J [Internet]. 2014 [cited 2019 Jan 17];51(2):172-7. Available from: https://journals.sagepub.com/doi/pdf/10.1597/11-278r

23. Eftekharian H, Zamiri B, Ahzan S, Talebi M, Zarei K. Orthognathic Surgery Patients (Maxillary Impaction and Setback Plus Mandibular Advancement Plus Genioplasty) Need More Intensive Care Unit (ICU) Admission after Surgery. J Dent Shiraz Univ Med Sci [Internet]. 2015 [cited 2019 Jan 17];16(1 suppl):43-9. Available from: https://www.ncbi.nlm.nih.gov/pmc/articles/PMC4476123/pdf/jds-16-43.pdf

24. Santos R, Sebastiani AM, Todero SRB, Moraes RS, Costa DJ, Rebelatto NLB, et al. Complicações associadas à osteotomia sagital dos ramos mandibulares. Rev Cir Traumatol Buco-Maxilo-Fac [Internet]. 2012 [cited 2019 Jan 17]; 12(1):77-84. Available from: http://revodonto. bvsalud.org/pdf/rctbmf/v12n1/a11v12n1.pdf

25. Tozzi U, Santagata M, Sellitto A, Tartaro GP. Influence of Kinesiologic Tape on Post-operative Swelling After Orthognathic Surgery. J Maxillofac Oral Surg [Internet]. 2016 [cited 2019 Jan 17];15(1):52-8. Available from: https://www.ncbi.nlm.nih.gov/pmc/articles/ PMC4759034/pdf/12663_2015_Article_787.pdf

26. Turgut HC, Alkan M, Ataç MS, Altundağ SK, Bozkaya S, Şimşek B, et al. Neutrophil lymphocyte ratio predicts postoperative pain after orthognathic surgery. Niger J Clin Pract [Internet]. 2017 [cited 2019 Jan 17];20:1242-5. Available from: http://www.njcponline.com/temp/ NigerJClinPract20101242-4340955_120329.pdf

27. Kim S, Jeon Y, Lee H, Lim JA, Park, S, Kim SO. The evaluation of implementing smart patient controlled analgesic pump with a different infusion rate for different time duration on postoperative pain management. J Dent Anesth Pain Med [Internet]. 2016 [cited 2019 Jan 17];16(4):289-94. Available from: https://www.ncbi.nlm.nih.gov/pmc/articles/PMC5564194/pdf/jdapm-16-289.pdf

28. Lima JAS, Luna AHB, Pessoa LSF, Alves GAS. Functional gains measured by MBGR and impact on quality of life in subject submitted to orthognathic surgery: case report. Rev CEFAC [Internet]. 2015 [cited 2019 Jan 17];17(5):1722-30. Available from: http://www.scielo.br/pdf/ rcefac/v17n5/1982-0216-rcefac-17-05-01722.pdf

29. Otero JJ, Detriche O, Mommaerts MY. Fast-track orthognathic surgery: An evidence-based review. Ann Maxillofac Surg [Internet]. 2017 [cited 2019 Jan 17];7(2):166-75. Available from: https://www.ncbi.nlm.nih.gov/pmc/articles/PMC5717890/

30. Aoki Y, Yoshida K, Nishizawa D, Kasai S, Ichinohe T, Ikeda K, et al. Factors that Affect Intravenous Patient-Controlled Analgesia for Postoperative Pain Following Orthognathic Surgery for Mandibular Prognathism. PLoS ONE. 2014;9(6):e98548. https://doi.org/10.1371/ journal.pone.0098548

31. Eshghpour M, Khajavi A, Bagheri M, Banihashemi E. Value of prophylactic postoperative antibiotic therapy after bimaxillary orthognathic surgery: a clinical trial. Iran J Otorhinolaryngol [Internet]. 2014 [cited 2019 Jan 17];26(77):207-10. Available from: https://www.ncbi.nlm.nih. gov/pmc/articles/PMC4196443/pdf/ijo-26-207.pdf

32. Martins T, Amante LN, Virtuoso JF, Sell BT, Wechi JS, Senna CVA. Risk factors for surgical site infections in potentially contaminated surgeries. Texto Contexto Enferm [Internet]. 2018 [cited 2019 Jan 17];27(3):e2790016. Available from: http://www.scielo.br/pdf/tce/v27n3/en_01040707-tce-27-03-e2790016.pdf 